\title{
1. The scope of the investigation: can absolutely anything be owned?
}

'Well! Some people talk of morality, and some of religion, but give me a little snug property'. ${ }^{1}$ I have in my day talked of both morality and religion, but now it is time to talk of property. Everything that is a property must have an owner, though ownership may be of things other than property, such as rights. However, in my investigation of the concept, I shall confine myself to the ownership of property, which is what 'ownership' in the commonest sense implies. For I want to discover, if I can, what it is actually like to own things, that is, what difference it makes to us whether we own something or not. But of course 'us' includes 'me'; and I am conscious that my investigation is necessarily conducted from my own point of view, and laden with my own prejudices. Properly scientific readers may therefore find it lacking in objectivity, indeed often lapsing into undisguised autobiography. I can apologise to them for this weakness but not, I fear, change its character.

I shall consider whether the private ownership of property can be judged an intrinsically good thing, or, on the contrary, whether having everything in common with other people is an ideal to which we should aspire, and whether common or shared ownership can have the same 'feel' about it as private ownership. And, crucially, I shall consider what is entailed by a thing having no owner, 'orphan' things, such as is the planet itself.

Lawyers have found it difficult to arrive at a definition of ownership. Ownership, they insist, is 'of things'. But since any possible object of discourse, from a pig to a philosophy of life, from a horse to a horoscope may be referred to as a 'thing', this does not help very much. In old-fashioned legal terminology, 'things' were called

1 Maria Edgeworth, The Absentee (1812) ch. 2. 
'choses', and were divided into two kinds, 'choses in possession', which are material objects such as buildings or jewellery, and 'choses in action' which are rights that can be enforced by legal action. In this chapter, I shall raise the question whether absolutely any 'thing' can be owned; and without giving a definitive answer to that question, I shall at least delimit the kind of 'things' ownership of which I shall be exploring, and rule out certain others, as outside the scope of this enquiry, which will be concerned, for the most part, with 'choses in possession'.

Whatever the difficulties of defining ownership, what is certain is that ownership is a complicated relationship between people, in that, if you claim to own something, you as owner are claiming rights which other people must respect. Now to talk of rights is at once to talk in legal, or quasi-legal terms. I am perfectly aware that philosophers and politicians talk of 'natural', or 'inalienable' rights, and though we now have the Human Rights Act on the Statute Book, there is no definitive list of such rights, nor any intelligible answer to the question how they came into being. For in normal language, if I claim a right, I am implying that this right has been conferred on me either by law or in virtue of some conventional relationship, such as being your pupil, your client, your customer or your spouse. To appeal to natural or human rights thus seems to me to be to use a metaphor, though one that is easily intelligible; it supposes a natural or moral law that lies behind, or is superior to, positive law. Thus Sophocles makes Antigone declare to the tyrant Creon that she is entitled by a greater law than his to throw dust on the body of her brother. In modern parlance, she is claiming that it is a human right that people should not be prevented from burying their dead according to their own conventions of decency. Broadly speaking, then, the idea of a human right is used to define what should be the proper relationship between an individual and the state of which he is a member. Ownership confers rights, because there are ways of acquiring things that are recognised by law, or at least by convention (I shall return to this in the next chapter), and it would be a violation of those rights if the owner were to be deprived, whether by another person or by the state itself, of the enjoyment of what is his.

Ownership, it should be observed, is not the only thing that confers rights: I may have a right of way or other right of access to land created by legally recognised usage that is undoubtedly yours, not mine. But this particular right must derive from some local 
byelaw, to which I can appeal if you accuse me of trespass. A jealous wife may claim that she has a right to know where her husband has been passing his time, because (probably unwisely) she regards the relation between husband and wife as necessarily entailing total openness. In a civilised society, that is, one where the rule of law is established, the law will protect not only a person, but his property; thus the concept of ownership and that of law are closely linked, indeed are central to such a society. If, without my consent, you take something that is owned by me you have committed theft, a criminal offence in any society that we would consider civilised; and if there were no such thing as ownership, there would be no such offence as theft. Historically, we may assume that laws have developed largely in order to define the rights of ownership as distinct from mere possession, that is, what you actually have about your person. As A.M. Honoré put it 'A people to whom ownership was unknown, or who accorded it a minor place in their arrangements, who meant by meum and tuum no more than "what I (or you) presently hold" would live in a world that was not our world'.2 And he later says 'When children understand that Christmas presents go not to the finder but to the child whose name is written on the outside of the parcel ... we know they have at least an embryonic idea of ownership'. ${ }^{3}$ It is this idea that I want to explore.

But, at the outset, we should recognise that 'meum' and 'tuum', 'his', 'our', 'their', though they are known in the grammar books as possessive pronouns (and sometimes referred to in America as 'ownership pronouns'), are not by any means always used to indicate ownership or possession. We speak naturally and intelligibly of 'my mother', 'my psychiatrist', 'my children' without in the least implying ownership. There is indeed a number of different uses of the possessive pronoun which absolutely cannot denote ownership. Take, for example, 'my country': while it is perfectly proper to refer to the ownership of pieces of land by the use of the possessive pronoun, as in 'my garden' or 'your field', to refer to 'my country' has no such connotation. Yet it may be used rhetorically as if it had. When the Countryside Bill was going through parliament in the year 2000, supporters of the Bill held up banners declaring 'The country

2 A.M. Honoré, 'Ownership', ch. 5 in A.G. Guest (ed.), Oxford Essays in Jurisprudence (Oxford University Press, Oxford 1961) p. 107.

3 Ibid., pp. 114-15. 
is yours' and 'Give us back our country'. These slogans involved not only two senses of 'country', but two senses of 'your'. To demand the 'right to roam' is a rhetorical device aiming to suggest that 'property is theft', and yet at the same time that the countryside is owned by the ramblers.

Let us return to the legal insistence that ownership is of things. This, as we have already seen, is hopelessly inclusive. But at least the proposition was put to powerful use in the Act of Parliament of 1833, which prohibited the ownership of living persons as property, the Act which abolished slavery. 'Things' do not and may not lawfully include people. In the same year, across the Atlantic, William Lloyd Garrison formed the American Anti-Slavery Society, and in 1854 he wrote:

I am a believer in that portion of the American Declaration of Independence in which it is set forth, as among self-evident truths, 'that all men are created equal; that they are endowed by their creator with certain inalienable rights; that among these are life, liberty and the pursuit of happiness'. Hence, I am an abolitionist. Hence I cannot but regard oppression in every form - and, most of all, that which turns a man into a thing - with indignation and abhorrence. ${ }^{4}$

A fellow human being is not a thing. But things may be living or inanimate; it is only human beings who are not things. I may properly enjoy full ownership of my pets.

Increasingly, moreover, 'things' that can be owned include nonphysical objects, such as patents, copyright, bright ideas and the research results that are the outcome of such ideas, 'intellectual' as well as material property. Ownership of property entails, among other things, the exclusive right to the use of the property by the owner, its sale if he wishes to sell, and, as we have seen, the possibility of the charge of theft (or in the case of copyright, plagiarism or piracy) against someone who unlawfully gains access to it. All these are 'choses in action'.

It is easy to see how the concept of intellectual property arose, by analogy with material property such as land, building or jewellery. Patenting was introduced in Britain three or more centuries ago, and the law governing intellectual property has grown more and more complex and controversial since the Copyright Act of 1956.

4 W.L. Garrison (1854), The Liberator, 4 July. 
Many people still think of the world of ideas as a world within which everything should be freely shared, especially since, if I share my idea with you, or with the world at large, I am not myself deprived of it, or its use. Moreover it seems (or seemed to the Coalition government in legislation proposed in 2012, but, at the time of writing yet to be enacted) that authors and composers have a duty to help to educate the young by allowing schools and colleges free access to their works. But authors and composers as well as inventors have to live, and it would be impossible for them to do so, if the concept of intellectual property were to be abolished. More worryingly still, freedom of information legislation threatens to allow open access to research in progress at university laboratories to anyone seeking it, regardless of the danger that incomplete or misleading results might thus be published. It is to be hoped that this legislation, also proposed in 2012, will be appropriately limited.

One way or another, with the growth of information technology, as well as the insistence on transparency in public life, the enforcement of laws designed to protect the ownership of intellectual property becomes increasingly difficult, some would say impossible. At any rate in what follows, I shall not be pursuing the issues that arise in connection with intellectual property rights. I am concerned solely with the ownership of material objects. This is the primary sense of 'ownership', going along with the primary sense of 'property', and it is this primary sense that I shall attempt to investigate further in the next few chapters.

Within this class of ownership, however, there are two particular cases which give rise to controversial questions, about which I must say something here. The first is the question whether we can be said to have ownership of our own bodies, while we are alive. A body is, after all, a physical or material object, though of an exceedingly complex kind. We have seen that we may not have ownership of other people's bodies while they are alive. Such ownership is slavery, officially abolished in the mid-nineteenth century. Slavery turned a man into a thing, and in doing so deprived him of freedom to make his own decisions and choices. Those who are not slaves retain these attributes: they can each say 'I am my own person'. But we have seen that the use of the possessive pronoun does not necessarily entail ownership; and there seems something irredeemably odd about saying that I own my body, though it is undeniably mine, not yours. The oddity lies, I believe, in the fact that I am too closely connected 
to my body for it to be my property. I am my body: there is no ' $\mathrm{I}$ ' separate from 'it'.

If I were René Descartes, or any other philosophical dualist, I might not find the concept of ownership of my body so strange. For Descartes famously believed that the only thing whose existence he could not doubt was the existence of himself as a thinking or doubting entity, a res cogitans as opposed to a res extensa, or physical object occupying space. 'I think, therefore I am.' Everything else in the world was different from this central 'I', because it was subject to Cartesian doubt, and could be imagined away as a delusion under the spotlight of radical scepticism. Mind and body were thus two completely different kinds of substance, mysteriously (and implausibly) conjoined through the rarified spirituous Pineal gland. Other animals than man were totally physical, moving mechanically, according to mechanical laws, incapable of thought or feeling. Man alone was essentially a rational, thinking being, conscious of his own self, and distinct from his body. Christianity, and especially the Platonism that exercised so powerful an influence on the early Fathers, encouraged such a belief. For Platonism taught that the soul of man was a temporary inhabitant of the body, longing to escape its limitations and tribulations, but, at least in aspiration, in control of the body while its sojourn on earth lasted. I, my rational thinking self, am like a leaseholder, with full rights of possession of the habitation which for the time being I occupy.

By now, however, it is hard to defend such dualism. For one thing, we cannot escape our post-Darwinian place in history. We, most of us, have no inclination to divorce ourselves completely, as Descartes did, from other animals. We know how much of our DNA, out of which our life is built up, is shared by non-human living organisms. Moreover we know, though still very imperfectly, how our brains function with our central nervous system, to give rise to physical feelings, emotions, memories and thoughts (all of which were classed by Descartes as 'pensés', 'thoughts', that which I discover by introspection and which can be articulated in language). And brains are physical objects. For me, therefore, my body, including my brain, is my way of being-in-the-world, my entrée into the universe. I cannot think of it as one of my possessions, just one among others.

English law confirms this common-sense view. If my grandson comes in, pouring blood, and says he has been mugged, we know that mugging is made up of two elements, assault and theft. He has 
lost a tooth in the attack, but he does not count this as theft. He has also lost his mobile phone; and this was the theft element of the crime. He did not own his tooth in the same way as he owned his phone. In the case $R v$ Bentham, ${ }^{5}$ the Appellate Judges in the House of Lords (now the Supreme Court) considered whether a person who concealed his hand under his jacket to give the impression that he was concealing a firearm there was rightly charged with being in possession of an imitation firearm, contrary to subsection 17(2) of the Firearms Act 1968. The original trial judge held that a person could be convicted on those facts, and the Court of Appeal upheld the decision. The House of Lords, however, reversed the decision of the Court of Appeal, and quashed the conviction. Lord Justice Bingham, summing up, said 'One cannot possess something which is not separate and distinct from oneself. An unsevered hand or finger is part of oneself. A person's hand or fingers are not a thing'. The jurist J.E. Penner also argues that all property rights are rights to things that are only contingently connected to an individual and are not intrinsic to a human being. The idea of separability is central to his concept of what constitutes a 'thing', and may therefore be the subject of ownership. ${ }^{6}$

The case of a severed hand or finger is, by implication, a different matter; and this is the second kind of case I must briefly consider (though only to rule it out from detailed examination), for it has become extremely controversial in recent years. In the invented case of my grandson, above, it could be argued that his tooth, once it had been knocked out, became his property over which he had rights of ownership, as much as over his mobile phone. The legal question, which is now much disputed, is this: who owns biological material, such as a tooth, derived from a particular individual who is its source? This question may arise, whether the material is a severed limb, an organ, a blood sample, or a sample of DNA. All such biological material has become enormously important in medical research, in organ transplant and in research carried out commercially by pharmaceutical companies, as well as in criminal investigations and in issues about proof of paternity. The question is whether the source of the biological material can claim ownership rights over

[2005]UKHL18; [2005]WLR1057(HL).

6 See J.E. Penner, The Idea of Property (Oxford University Press, Oxford 1997) p. 111. 
it, or whether the ownership lies with the individual or institution that actually holds the material, or whether each case must be judged separately, in the light of the circumstances. It would have been reasonable to hope that, in English law, such issues would have been settled once and for all by the passage of the Human Tissue Act in 2004. However, the uncertainty remains.

The Human Tissue Act came onto the Statute Book following two scandals, chiefly involving the Children's Hospital in Liverpool (Alder Hey), and the Bristol Royal Infirmary (though other NHS National Health Service - hospitals were later shown also to have been involved) where large numbers of body parts, whole organs and tissue, taken from children who had died in hospital, had been retained without the knowledge or consent of their parents, and, at Alder Hey especially, for no apparent purpose or use. Here a particular, possibly unbalanced, doctor from the Netherlands seems to have been responsible for most of the collection and retention of the organs. The outrage was enormous, and, to the embarrassment of the Church, often led to a demand for a second or even a third burial service, as a body part came to light. It was important to many of the parents that their child should have been buried, as they had supposed, complete and intact. 'How can she love us from heaven without a heart?' one mother wrote, in a letter to a newspaper.

However irrational the response, the scandals had a serious effect on medical research and organ transplant, donors and, especially the relatives of potential donors refusing to trust so flawed a system enough to give the necessary consent. It was natural, therefore, that the new legislation should concentrate mainly on the matter of consent, especially consent from relatives for the use of body parts, and should not directly address the question of who, if anyone, owns them.

The second reason for the failure of the Act to address the problem of ownership is the long tradition in English Common Law (and in Australia, Canada and the USA) that complete dead bodies can have no owners. This principle is known as the 'No Property Principle', and can be traced back at least to the mid-seventeenth century. At that time Sir Edward Coke, in his book The Institutes of the Laws of England, ${ }^{7}$ gave an agreeable explanation. He argued that the No Property

7 E. Coke, The Third Part of the Institutes of the Laws of England (London, 4th edn 1669) vol. III p. 203. 
Principle was self-evident, if one thought about the etymology of the word 'cadaver' (corpse). 'Cadaver' was short for 'Caro Data Vermibus' ('flesh given to the worms'). If it had been given to the worms it could not belong to anyone else. Obviously, this bogus etymology contains no truth whatsoever. But despite its extremely dubious derivation, the principle survived, so that William Blackstone, a century or so later, stated, of grave-robbers, that 'stealing the corpse itself, which has no owner, though a matter of great indecency, is no felony, unless some of the grave-clothes be stolen with it' ${ }^{8}$

The debates in the House of Commons and the House of Lords on the Human Tissue Bill make no reference to property or ownership. It is true that consent to keep or use might imply ownership, as I might give consent that you should drive my car when yours has broken down. But it need not do so. I must consent to a surgeon's cutting up my body, but this is an appeal to the principle of autonomy rather than that of ownership, since we have seen that I do not own my body. And it seems that the emphasis on consent in the context of retaining body parts is an extension of this same principle, parents exercising autonomy on behalf of their children, as is always the case. The principle of autonomy, or patient choice, which in the last twenty years or so has formed a major part of medical ethics, and is taught like a gospel to medical students, dominated the thinking behind the Human Tissue Act, so the question of ownership was forgotten.

Some years before the passage in England of the Human Tissue Act 2004, however, the courts in the USA were forced to confront the problem of ownership of body parts head on. This was in the case of Moore $v$ Regents of the University of California, a case which is often taken by jurists and bioethicists as the starting point of any debate about the ownership of body parts. In 1976 John Moore visited the UCLA medical centre after he had been diagnosed as suffering from leukaemia. There the diagnosis was confirmed, and his doctor, Doctor David Golde, recommended that his spleen be removed. Moore signed a written consent form for the splenectomy which was duly carried out. There was nothing in the consent form that referred to the future use of the spleen when it had been removed. Over the next seven years, while Moore frequently returned to the medical

8 W. Blackstone, Commentaries on the Laws of England (Clarendon, Oxford 9th edn 1783) vol. IV p.2. 
centre to give samples of blood, blood serum and cells from skin and bone-marrow, Dr Golde and his assistant, Dr Shirley Quan, were attempting to establish a cell-line from the cells of Moore's spleen which were particularly useful, since they overproduced certain lymphokines, that is, substances related to white blood cells and activated by contact with antibodies. They thus played an important role in the immune system. By 1979, Golde and Quan had succeeded in producing a cell-line from the spleen. This meant that they had virtually turned the cells from Moore's spleen into stem cells that could reproduce themselves for ever, and be used either for direct transplant into other damaged tissue, or for the creation of drugs for enhancing the immune system. The process that they had discovered to establish the cell-line was therefore of enormous potential value, both scientific and commercial. In 1984 the University of California was granted a patent for the process, and for methods of using the cell-line that had been set up, whose commercial value was estimated as $\$ 3$ billion over a period of six years. The Regents of the University immediately entered into agreements with a genetic research institute and a pharmaceutical company, granting rights of access to the cellline (which, incidentally, was one of the few cell-lines in the United States that survived the axe of George W. Bush more than a decade later, when he, absurdly, called a halt to all stem-cell research, but allowed existing cell-lines to remain).

Although Moore had frequently attended the medical centre since his first visit in 1976, it was not until 1983, just before the granting of the patent, that he was asked to sign a consent form that would permit continued research on his spleen, which referred to rights that he had over the use of the spleen. He was requested to hand over the form with his signature to the Regents of the University. However, he refused to sign. He then brought an action, naming five defendants, the two doctors, the Regents of the University and the two companies to whom rights had been sold. He named no less than thirteen causes of action, of which only one, the tort of conversion, was taken up by the courts. The tort of conversion is 'wrongfully dealing with a person's goods in a way that constitutes a denial of the owner's rights or an assertion of rights inconsistent with the owner's'. ${ }^{9}$ In such a case the plaintiff has specifically to

9 Concise Dictionary of Law (Oxford University Press, Oxford 1983). 
prove ownership. This meant that Moore had to prove that he was the owner of his spleen which had been removed with consent seven years earlier. Moore lost his case at the first (Superior) court, and proceeded to Appeal. The Appeal Court, by a majority, upheld the appeal, but failed to establish that they did so on the grounds that Moore owned his spleen. They contented themselves with asserting that he had rights of control over the uses to which his body parts should be put, and also, rather oddly, that to deny this kind of control would constitute an 'invasion of privacy'. (The concept of privacy is closely connected with that of ownership in other contexts, as we shall see; but it seems somewhat bizarre in the particular case of Moore's spleen, which was no longer part of his body, and with which he had had no connection for years.) The Regents of the University and the other defendants appealed against this judgment, and the Supreme Court of the State of California reversed the decision of the Court of Appeal, by a majority decision. The majority held that though Moore might have a case against Dr Golde for failing to get his informed consent for the use of his spleen, he had no case in tort of conversion, since he did not retain any proprietory interest in his spleen, once it had been removed: it was, in short, of no further use to him.

But this is surely to beg the question. What is needed is a decision as to who owns the spleen at the moment when it is removed. I gave birth to one of my children in a small nursing home where I could look out into the garden and see the two nurses who ran it (dishearteningly called Nurse Payne and Sister Screech) digging the placentae of their patients into their rose beds. I remember feeling mild resentment. I thought my roses too might have benefited. But whether or not I had used the placenta to fertilise my garden has no bearing on the question whether it was indeed mine (later I learned that, at least in some American birth centres, the women are sent home each with her placenta in a plastic bag, plainly as part of her belongings). However this may be, we should ask whether Moore's case would have been stronger in law if he had happened himself to be a research scientist in the field of human cells. For he would then have had a continued ownership interest in the biological material. But the law surely cannot turn on such an accident as the profession of the patient. One of the dissenting judges at the Californian Supreme Court held that because patients should have a right to control the subsequent use of what had been parts of their body, this right 
should be protected by conversion law. The other dissenting judge simply denied the truth of the proposition upon which the judgment of the majority appeared to rest, namely that the concept of ownership could have no application to detached body parts. After all, in cases of transplant, an organ can be given as a gift. One cannot be a donor unless one owns what is donated.

In the end the decision against Moore's claim to participate in the profits derived from his spleen seemed to rest on matters of policy rather than of strict principles of justice: it was held by the majority of judges that, though in some circumstances it might be appropriate to claim ownership of body parts, in the case of Moore and others in a similar situation, the effect on medical research would be disastrous if his claim were allowed. The incentive to research would be diminished if profits were to be shared, and thus so drastically reduced. The judgment seems to have been pragmatic; but it may serve as a precedent that will ultimately determine disputes about the ownership of detached body parts and tissue. No one can doubt that they are 'things'. ${ }^{10}$

There is another alleged reason for a resistance to the notion that body parts should be classified as property, owned by the person of whose body they are part. If they were so classified, it would be open to anyone to sell one of his kidneys. At present this is not lawful either in the UK or in the USA. If ownership by living people of separate, or separable, body parts were permitted, the right to dispose of them by sale would be included in the package of rights that belong to the owner. It is widely held that it would not be in the public interest to change the law in this respect, since it might lead to the exploitation of the most poverty-stricken members of society, who would risk their health and even their lives by giving up one of their kidneys for profit.

Most kidneys for transplant are acquired either from relatives of the patient in need who are of matching blood group, or from newly dead corpses, especially of those who have been killed in road or other accidents. But such a source is chancy, and subject to

10 For a full critical examination of the Moore case, and many other cases, with all the relevant references, see R. Hardcastle, Law and the Human Body (Oxford University Press, Oxford 2007) especially pp.65-71, the source from which, as I gratefully acknowledge, I have learned most of the facts of Moore. 
disastrous delays, if consent has to be obtained from relatives (few victims of accidents carry donor cards). Very few people donate a kidney, as they may donate blood, to an unknown recipient, out of generalised benevolence. The result is a great shortage of organs for transplant and a long waiting list of patients on dialysis, many of whom die before they reach the top of the list. There are those, therefore, who believe that a regulated NHS-run market in kidneys should be established, which would save lives and save the cost to the health service of treatment and dialysis. ${ }^{11}$ Public opinion seems generally hostile to such a change, partly, no doubt, because of the risk of exploitation, but partly, I suspect, out of a kind of squeamish distaste for an open market in body parts, though it is known that people, for example in India, do sell their kidneys for cash. There seems to be some redeeming virtue in donation, even posthumous donation, rather than sale. But we must recognise that this is an issue that can only grow more urgent.

Problems similar to those of donated organs arise more and more frequently in the case of donated eggs and sperm for assisted fertilisation. Once again, the very idea of donation suggests ownership of what is given; yet, perhaps because these 'things' are so nearly human beings, so essential to any resulting human embryo, there is an understandable, though not wholly rational, squeamishness about setting up a market in which such goods may be sold competitively. As usual in Europe, the matter is settled by regulation and convention.

As Rohan Hardcastle concludes in the book already referred to, ${ }^{12}$ the present state of the law regarding rights over separated body parts, including cells and cell-lines, is confused. He argues that the basis should be ownership, and that ownership should lie with the source of the biological material, as John Moore had claimed in the 1980s. The owner could then be asked to donate the material, or alternatively would have to be paid for its use. The cost involved to medical research institutions and pharmaceutical companies would, he admits, have to be carefully estimated. Account

11 See, for example, an article published online by the British Medical Association on 3 August 2011 by Dr Sue Eabbitt Roff, a renologist from the University of Dundee. The BMA itself made it known that they would not support such a change in the law.

12 Op. cit., pp. 293-4. 
would have to be taken, for example, of the number of women who, in the euphoria of childbirth, might voluntarily donate their placenta and umbilical cord, rich sources of stem cells (though of a limited variety), for use in research or therapy. However, my guess is that the cost to research, academic or directly commercial, would be enormous, and ever-increasing with the discovery of new techniques in the field of cell manipulation and cell transplantation. I believe that the step from consent to the use of biological material to ownership of it by the source will be taken, if at all, with extreme reluctance, whatever the demands of clarity or natural justice.

Hardcastle acknowledges that such a change in the law, to give sources clear ownership rights over their organs, might give rise to an open market for the sale of kidneys, rather than a market regulated by NHS commissioners, and demand for kidney transplant might be such as to make prices unaffordable by the NHS. But that would not necessarily follow. All ownership is subject to the limitation that the use of the property must not be damaging (for example, if I live in London, I may not cut down a tree in my garden and make a bonfire of it); and it could, as we have seen, be argued that to put the poor at risk of self-harm would be to damage not only individuals but also a society which aims for at least a show of equality. Some system of cap on prices demanded might be enforced.

In any case, at present, despite the Human Tissue Act and the onetime existence of a body entrusted with overseeing the implementation of the Act, the status of biological material in England is unclear (and the position is no better in the USA and Australia). As we have seen, separation from a living body turns biological material into a 'thing', capable of being the subject of ownership, or property. But the question of whose property it may be, its source or those who would use it, is subject to an important provision. It is held that the application of 'work and skill' to the 'thing', whether spleen or placenta, serves to create property rights and ownership for the person whose work and skill is employed. For the skill is held to change the original 'thing' in question into another, different 'thing'. This new thing could be a permanent cell-line, for example, or even, according to the first appearance of the principle, ${ }^{13}$ a part of a collection, or a

13 In Australian law: Doodeward v Spence 1908. 
teaching aid. The work and skill in the latter case would be the work of fixing and preserving the thing in question, which may indeed have been a laborious process.

The Australian case, an appeal against a judgment of the Supreme Court of New South Wales, is highly instructive, if somewhat macabre. In 1868 a woman gave birth in New Zealand to a baby with two heads. The baby was still-born, and the doctor arrived after the birth, and took the dead baby away and preserved it as 'a curiosity'. After his death in 1870 , the preserved baby was sold at auction, and came into the possession of a Mr Doodeward. However the police came to hear of it, and a policeman (Spence) removed the preserved baby from its apparently legitimate owner, for it to be given a Christian burial, on the grounds that there can be no ownership of a corpse, but that it may be lawfully retained only between its death and its burial, in this case a period of forty years. Chief Justice Griffith held that the work and skill put in by the doctor who had first removed the dead baby had turned it into a thing different from a corpse; and that in any case, by analogy with the possession by students and teaching hospitals of skeletons or other anatomical parts of human bodies, the law must respect property rights over such material:

It is idle to contend in these days that the possession of a mummy, or of a prepared skeleton, or of a skull or other parts of a human body is necessarily unlawful; if it is, the many valuable collections of anatomical and pathological specimens or preparations formed and maintained by scientific bodies, were formed and are maintained in violation of the law.

The Human Tissue Act 2004 gave ownership rights over whole mummified bodies or shrunken scalps to the original (mostly Aboriginal) sources and made it lawful for national museums, at that time prohibited by law from disposing of any of their holdings, to return them to their country of origin if requested to do so (a further exception has since been made for objects acquired by looting or forced sale from families persecuted by the Nazis between 1933 and 1945). But, as we have seen, this was not on the basis of work and skill having been applied to change the attributes of the 'things' but because consent had not been given to their being held in the museums in the first place. Nevertheless, however uncertain the 'work and skill' proviso is (and the eminent gynaecologist, 
Lord Naren Patel, remarked in his speech in the second reading debate of the Human Tissue Bill on 22 July 2004 that the interpretation of case law in this matter was far from straightforward), it may possibly afford a way out of the difficulty, described above, of allowing ownership to the sources of separated body parts. For it could be argued that the undoubtedly skilful surgery required to remove a spleen or a tumour had transformed the 'thing' that had been part of the patient's body into a different 'thing', a cluster of cells useful for research or educational purposes.

The ownership of body parts is, as I have said, an issue that is not only historically complicated, but likely to become increasingly contentious with the advance of sophisticated microbiological research. Yet I shall say no more about it in what follows. My consideration of ownership will, from now on, follow a different track. As I have explained, I want to explore what it is actually like to own something, and especially to own a part of one's immediate environment, a house, a garden, two acres and a cow; in short, what it is like to own a property. This might, in currently fashionable usage, be described as an exploration of the existential nature of ownership.

I shall consider what difference it makes to one's attitude to a 'thing' whether or not one owns it, and what difference it makes to one's responsibilities, or one's feeling of responsibility, for the maintenance, wellbeing or preservation of that thing. (Incidentally this close connection between ownership and responsibility is reflected in the currently common use of the word 'ownership' actually to mean 'responsibility'. Thus the chairman of a board may say to a board member 'I will give you ownership of that project'.)

We must also examine to what extent the feeling that something belongs to me and not to you (surely a most ancient and instinctive feeling) may be transferred to common or joint ownership, when the 'thing' belongs to us and not to them. Is it possible to conceive of something that is owned by everyone in the world, or is this a contradiction? And are there things (like human beings, alive or even perhaps dead, as we have seen) that we wish that nobody may own, such as wild animals and birds, and wilderness?

There is no doubt that the concept of what is mine and not yours is deeply embedded in the psychology of the individual. But it is also a political concept of great consequence, embedded as it is in law and therefore in the idea of civil society. Such ideas, of course, are 
not static, but change throughout history. But philosophers, from Plato onwards, have sought to clarify the concepts of political life by going back to their origins, or rather to their imagined origins, when life was simpler, and when no political institutions yet existed. It is to such imagined origins of society, and thus of property that we must now turn. 